\title{
Perspective
}

\section{Herbicide resistance costs: what are we actually measuring and why?}

\section{Roger D Cousens* and Alexandre Fournier-Level}

*Correspondence to R Cousens, School of BioSciences, The University of Melbourne, Victoria 3010, Australia. Email: rcousens@unimelb.edu.au

\begin{abstract}
Despite the considerable research efforts invested over the years to measure the fitness costs of herbicide resistance, these have rarely been used to inform a predictive theory about the fate of resistance once the herbicide is discontinued. One reason for this may be the reductive focus on relative fitness of two genotypes as a single measure of differential performance. Although the extent of variation in relative fitness between resistant and susceptible plants has not been assessed consistently, we know enough about plant physiology and ecology not to reduce it to a single fixed value. Research must therefore consider carefully the relevance of the experimental environment, the life stage and the choice of metric when measuring fitness-related traits. The reason most often given for measuring the cost of resistance, prediction of the impacts of management options on population dynamics, cannot be addressed using arbitrary components of fitness or a fixed value of relative fitness. To inform management options, the measurement of traits that capture the relevant processes and the main causes of their variation are required. With an emphasis on the benefit of field experiments measured over multiple time points and seasons, we highlight examples of studies that have made significant advances in this direction.
\end{abstract}

@ 2018 The Authors. Pest Management Science published by John Wiley \& Sons Ltd on behalf of Society of Chemical Industry.

This is the author manuscript accepted for publication and has undergone full peer review but has not been through the copyediting, typesetting, pagination and proofreading process, which may lead to differences between this version and the Version of Record. Please cite this article as doi: $10.1002 / p s .4819$

This article is protected by copyright. All rights reserved. 
Keywords: herbicide resistance, fitness cost, relative fitness, experimental design

\section{INTRODUCTION}

\subsection{Why measure fitness cost of resistance and not use it?}

It has become almost an expectation that studies of new cases of herbicide resistance must determine, along with the biochemical mode of action, if there is any "fitness penalty" or "resistance cost" incurred by resistant plants in the absence of the herbicide to which resistance had evolved. The reason for doing this is rarely stated explicitly, although most assume that it will relate to the persistence of the resistance gene(s) in the population when the selecting herbicide is not used ${ }^{1,2} \square$; thus, there is the possibility of working out how to modify the management system appropriately ${ }^{3-6} \square$. The fact of the matter is that nothing further is done with most of the published estimates of resistance cost other than to compare their existence or apparent non-existence with other studies.

We believe that there are several reasons why resistance cost estimates have been consigned to mere lists:

i. The quantities typically measured experimentally as "resistance cost" are usually only a fraction of what is needed to capture fitness appropriately. With the many other parameters required for drawing useful predictions remaining unknown, it is difficult to do anything with these measurements other than to tabulate them.

ii. The way to manage agricultural systems to avoid or to respond to resistance is clear without knowing accurately the magnitude of resistance cost. Thus the focus of applied research has been restricted to Integrated Weed Management (IWM), the development of multiple options to reduce seed banks, and its communication to farmers.

iii. It has become a habit to test for the presence of a resistance cost, rather than to quantify useful life-history parameters and the variation thereof. The conclusion drawn is frequently that there is no resistance cost, with a severe possibility of Type II statistical error, and so no follow-up research ensues.

iv. The valid research aim may be a very simple one which requires no further elaboration. For example, the existence or absence of an effect of resistance on plant growth may 
be needed to provide support for the proposed physiological mechanism responsible for resistance. Nothing more.

Whatever the reason, the tradition of trying to measure resistance cost - with little use of the results - continues. There are no doubt some valid reasons for measuring resistance costs usefully. But we have great concerns that, with a few notable exceptions, researchers are measuring the wrong thing, for the wrong reasons, with the wrong expectations. As a result, the quantities we compare in our lists of resistance costs are measured in so many different ways that we cannot have any confidence in their relativities. We do not argue that all work on resistance penalties should be disregarded; but rather wish to ensure that future work will be designed to be useful, with studies beginning by specifying the utility of the results.

\subsection{What is fitness?}

To understand what a useful estimate of fitness cost could be, we should first consider what fitness is (and by extension what it is not). Despite a long history of theoretical discussion by evolutionary biologists ${ }^{7-10} \square$, the basic concept behind fitness is simple. The fitness (w) of a particular genotype (i) in a particular environment represents its success in contributing individuals $\left(n_{t}\right)$ to the next generation, i.e.

$$
w_{i}=n_{i}(t) / n_{i}(t-1)
$$

If we are interested in the population consequences of herbicide use, this definition is sufficient. $w$ can be estimated by monitoring numbers of each genotype over multiple consecutive generations, aided by the fact that the herbicide provides a readily available assay. This can be achieved relatively easily within farming systems and has the additional benefit of accounting for local environmental and genetic heterogeneity. If we are only interested in the fitness of one genotype relative to another - as we usually are - we would only need to monitor their relative frequencies rather than absolute numbers, an option that is becoming cheaper and easier with sequencing technology.

Nonetheless, the "black box" definition in Eqn (1) is uninformative about the influence of individual traits on fitness and hence about the processes involved in the frequency dynamics of the different genotypes. This is inherently limiting from both 
scientific and practical management perspectives. We can partly overcome this weakness by subdividing fitness into a survival and a fecundity component, which can be estimated separately. Thus, a slightly more mechanistic definition of fitness adopted by many empiricists is:

$$
w_{i}=P_{i}(S-R) P_{i} \text { (lifetime) }
$$

i.e., the product of the proportion of seeds that goes on to become reproducing plants and the lifetime reproductive output per mature plant. Survival from seed dehiscence to reproductive maturity $P(S-R)$ is not at all easy to measure. It is the combined outcome of seed predation, mortality within the seed bank, establishment, survival and so on. Unless the population is highly synchronised, lifetime fecundity may also be complicated to estimate, particularly when a measure of fecundity must take into account the entire life span of the plant. Equation (2) can be decomposed almost indefinitely to separate out the different components of the lifecycle.

\section{HOW TO MAKE THE ESTIMATION OF FITNESS-RELATED TRAITS USEFUL}

\subsection{Predicting the fate of herbicide resistance}

The most direct way to assess the fate of herbicide resistance, only relying on the first definition of fitness (Eq. 1), is without question the use of experimental evolution studies ${ }^{11-}$ 13. These imply long experiments running over multiple generations and with major difficulties of thoroughly controlling the experimental factors tested. A less laborious and more widely used approach to predict the evolution of herbicide resistance is modelling, in which shorter-term experiments can be used to estimate appropriate parameters.

Various classes of models of increasing complexity have been used to describe herbicide resistance evolution ${ }^{14}$. Early models typically focused on a population as an entity, with the advantage of being very informative and straightforward but often holding parameters constant, making the models at best very abstract if not completely theoretical. More recently, individual-based models have increased the flexibility in the way trait relationships (i.e. processes) can be specified with the potential for these relationships to change over the simulation. The outcome is a greater mechanistic insight, potentially making a more extensive use of empirical data, which is evidently more helpful for 
management purposes. But this flexibility often comes at the expense of simplicity, making them more labour intensive to parameterise.

Most early models of herbicide resistance dynamics were process-based models $^{1,15,16}$ where the fitness cost of resistance was often parameterised as a single value ranging from 0 to $1^{1,6,15,17,18} \square$, this single value being sometimes extracted from experiments $^{8}$ but more often than not chosen arbitrarily, ${ }^{6,19,19}$ and its influence tested through a sensitivity analysis ${ }^{6,15}$. Perhaps the high exposure received by these studies was a major reason that the weed research community felt the need to shrink the outcome of potentially complex situations down to a single quantity. These models were excellent for illustrating principles, but otherwise limited. Herbicide resistance modelling thus turned away from fitness costs as a single scaling parameter, to embrace a more realistic level of complexity, trail-blazed in some early efforts ${ }^{16,20}$ and more recently extended to individual-based approaches ${ }^{5,21}$. Fitness costs are not incorporated directly but emerge as a consequence of many potential changes in lifecycle parameters between resistant and susceptible biotypes, including for instance variation in competitiveness ${ }^{20,21} \square$ or flowering time ${ }^{5}$. Models should be seen as a great opportunity to use the full extent of experimental data available, as well as to identify crucial experiments that would fill in gaps or test specific model assumptions. Another important feature is the way in which models integrate both processes and traits - rather than merely traits - for a comprehensive

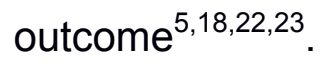

\subsection{What to measure: beyond biomass}

The evolution of resistance can impact numerous traits involved in multiple processes and ultimately alter fitness in many different ways. However, studies focusing on fitness cost of herbicide resistance have primarily focused on plant biomass and productivity ${ }^{24-31} \square$. We acknowledge that total seed production is often a good proxy for fitness and, in many cases, primary biomass production is indeed a good predictor of seed output ${ }^{32}$. However, this by no means implies that measuring only productivity will adequately capture the full differences between resistant and susceptible biotypes. Other factors such as life-history traits $^{13,22,33,34}$ or response to biotic ${ }^{35}$ and abiotic ${ }^{36}$ conditions may also play an important 
role. And on an individual plant level, biomass may make no sense as a measure of fitness: a large but sterile or dead plant clearly has no progeny and zero fitness - even though it may have substantially affected the fitness of its neighbours.

The number of offspring a plant contributes to the next generation is the net outcome of all stages of the plant lifecycle ${ }^{37}$. Many models of resistance thus use the lifecycle of a plant as a template. If our research aim is to predict the dynamics of resistance, it would make obvious sense if our data-gathering also used the same lifestage structured template. Depending on the nature of the resistance, we might expect performance at any or all stages to be affected. We must therefore be comprehensive in comparing genotypes at all stages, not just those that are convenient to measure. The risk of measuring only one stage, such as early plant growth, is that it may be the "wrong" stage in terms of finding out whether or not there is a fitness cost and may not reflect the overall lifetime fitness difference between genotypes.

In recognition of this, it has become increasingly common to examine more than one "component" of fitness and list how each of these is affected (in the absence of herbicide) by resistance: for example dormancy ${ }^{22}$, germination $^{22,34}$, early growth ${ }^{34}$, flowering ${ }^{13}$ and seed production. Although telling us biologically interesting, perhaps even useful information, there is still the real possibility of missing out key stages. Added to this, there is the problem of bringing the various components together to measure the overall fitness cost. It is not simply a matter of averaging or multiplying the components, although this has been the approach used in some fitness indices ${ }^{38} \square$. We expect, for example, the influence of stages early on in the lifecycle, such as rate of germination and early vigour, to be magnified by processes such as competition later on $^{39} \square$ and competitive superiority of one genotype over another may change considerably during growth ${ }^{40,41} \square$. How do we compare quantitatively the effects on dormancy with those on growth or mortality? Once again, the answer is to consider fully-parameterised models rather than a piecemeal selection of arbitrary stages.

The focus on population dynamics ${ }^{42,43} \square$ has been valuable, especially from a weed management perspective ${ }^{44} \square$. However, if we want to delve deeper into physiological changes resulting from resistance and how they will affect fitness, empirical counts of the 
numbers of individuals germinating, dying and being born will be insufficient. To illustrate a few possibilities, height, leaf area, root length and water use efficiency, especially early on, are well-established as important traits in competition with other genotypes and with a crop, impacting on plant mortality (density-dependent and -independent) and further growth of survivors. There might be effects on stigma-pollen interactions, pollen-tube growth and even attractiveness to pollinators, determining the plant's level of outcrossing and its contributions to heterozygote progeny. Pleiotropic effects on seed protein, carbohydrate and secondary metabolites could alter dormancy, survival in the seedbank, seedling ability to grow from depth and to survive disturbance, as well as pathogen infection and predation rates.

\subsection{Targeting key fitness traits for management}

Ideally, we need a model that is mechanistic, at least for growth and development, to go with such measurements; mechanistic "eco-physiological" models are available and even better - functional-structural models ${ }^{45}$ could be developed. Unfortunately, the effort required to parameterise mechanistic models is such that they are unlikely to be developed for most situations; indeed, the use of eco-physiological models for weed-crop competition has waned since the mid-1990s.

Notwithstanding our argument that measuring just a few components of fitness could lead to unreliable predictions of resistance dynamics, there may be circumstances in which our objectives require the identification of only the most influential traits. For example, this may help identify the prime target stages among a number of IWM options or the priorities for future detailed research. There are rigorous ways of doing this other than through modelling, provided that at the outset we collect a large amount of data. We can apply various multivariate discriminant analyses such as principal component analysis or canonical correspondence analysis ${ }^{33,46} \square$ to see which have the most influence. Another option widely adopted in evolutionary studies is to compute the matrix of genetic variance and covariance between standardised traits, the "G-matrix" 47,48 . This is, to our knowledge, the most powerful way to evaluate first the redundancy among traits and second the contributions of each trait to fitness. This would allow the measurement of fewer traits that 
are more directly connected to overall fitness in future work. The G-matrix can also be used to identify the extent of pleiotropy between herbicide resistance and each trait, and to measure directional selection on multiple traits. This approach is used under the term "selection gradient analysis" 49 . The selection analysis framework has only occasionally but rather convincingly - been used to identify pleiotropic effects of resistance ${ }^{12,46,50,51}$ on productivity and life history traits.

Regardless of the mechanisms involved, it can be argued that traits appearing to co-vary with resistance should be the prime targets of integrated pest management approaches. Moreover, the correlation between productivity traits and their effect on fitness may well vary for different life history stages ${ }^{52,53} \square$. It is easy, however, to overlook potentially important traits. Pleiotropy may be obvious in coarse measures such as biomass at some arbitrary time (reflecting the growth rate of established plants), but there is every reason to expect more subtle effects - though still with significant consequences for population dynamics.

\subsection{Experimental design and the competition conundrum}

Fitness is dependent on the environment in which a plant grows (i.e. it is contextdependent) and the biotic environment cannot be ignored: weeds can have large effects on crop growth and vice versa. It is surely unwise, therefore, to measure fitness of weeds in the absence of a crop or to assume that fitness will be the same within all crop species in a rotation. Plant growth is also affected by the supply of the resources for which plants compete. A great many studies investigating resistance costs have been performed under closely controlled conditions, primarily planting the tested genotypes in potting mix under greenhouse conditions ${ }^{28,29,31,54} \square$. While we do not reject the qualitative conclusions reached by these studies, given the focus we have placed on the usefulness of the estimates obtained, it is obvious that an experiment performed in cropping field conditions will be more reliable than its greenhouse counterpart. Studies measuring competition in fields and other natural environments have been conclusive $\mathrm{e}^{51,53} \square$ and despite the technical difficulties and the inherent variation introduced by a less controlled environment, proved useful. 
Two related aspects of the measurement of fitness cost concern the density at which to grow the resistant and susceptible genotypes and whether they should be grown together in mixtures. Competitiveness can differ greatly between resistant and susceptible genotypes and opinions on the "correct" experimental procedure to measure it can be strong, dare we say dogmatic, in some cases. There are those, especially with ecological training in the 1970s and 1980s, who remain faithful to the replacement series design $^{20,28,29} \square$ where the two competitors are grown alone and in mixtures, all at the same total density; there are also those who consider that the replacement series design has no place in science and should be banned ${ }^{55} \square$; and there are those who pay no attention to the possibility of density- or frequency-dependence. We simply do not know how much estimates of resistance cost vary with choice of experimental design. But we know enough to be cautious.

Basic ecological theory predicts that as abundances increase, plants will increasingly compete for resources - both with their own kind (either at the species or at the genotype level) and with others. Their environment will change and so will their demography. The growth of individuals and their probability of survival will decrease simultaneously (the population will "self-thin" ${ }^{56} \square$ ), altering their average number of offspring per plant. But will it matter to the average relative fitness of the two genotypes? If relative fitness does change with the competitive environment, it will certainly not be possible to specify a single density or relative frequency to use in an experiment. "Competitive fitness" measured in some studies ${ }^{57} \square$ is also liable to be density- and frequency-dependent (notwithstanding the problem with basing fitness on just part of the lifecycle). Logically, then, we should make measurements under a range of densities and proportions ${ }^{31} \square$; by fitting a response-surface model $^{58} \square$ to the data we could estimate fitness cost at any abundances of the genotypes. The experiment may become more onerous, but the results are more useful for making population predictions.

Another avenue to alleviate excessive experimental complexity would be to run simulations using an eco-physiological model of weed-crop competition ${ }^{59} \square$. Instead of trying different competition designs in vivo, we could use sensitivity testing in silico to see what size of variation in fitness cost we might expect from this confounding factor; we 
could even explore which traits, and what magnitude of variation in those traits, would result in fitness differences that would be detected as statistically significant in a reasonable experiment.

\section{HOW CAN TRAIT ESTIMATES BEST REFLECT DIFFERENCES BETWEEN R AND S BIOTYPES?}

\subsection{Avoiding the type II error trap}

There is a logical contradiction between the way we view resistance scientifically and the way we analyse and interpret our data. For a new occurrence of resistance we could reasonably expect an effect on fitness to be anywhere along a continuous scale from zero to very large ${ }^{17} \square$. Some mutations may have a major physiological effect that can be detected almost regardless of how good our experiment is. But we mostly expect cases in which the impact in the absence of herbicide will be small or perhaps nil.

Having obtained experimental data, it is standard practice to examine a null hypothesis of no effect and ask if we can reject it: if the test is non-significant, then we conclude there is no effect whatsoever. We are, therefore, starting with the a priori assumption that there cannot be small effects on fitness! Or, equivalently, that the only relevant effects are so large that they can always be detected above background noise ${ }^{60} \square$ (i.e. we deny the possibility of what statisticians refer to as Type II error, or false negatives).

There is always a residual error in any experiment, even the largest one carried out by the most fastidious of professionals. On examining an ad hoc selection of herbicide resistance fitness papers drawn from published reviews, it would appear that a coefficient of determination (Standard Error, SE, divided by the mean) of $10 \%$ is typical, $5 \%$ might be about the best we can do and occasionally only $20 \%$. Interpreting the LSD as a crude measure of an experiment's limit of detectability (and for $p$-value $=0.05$, it is roughly 3 times the SE), we must appreciate that a typical experiment is likely to miss (i.e. conclude as non-significant) a real effect on fitness as large as perhaps $25 \%$. Surely this should be a concern to researchers? 
There are various ways to increase the power of an experiment, such as choosing uniform experimental material and units, increasing replication, and so on. But it is an inescapable fact that there will always be a limit to the size of trait differences detected using an hypothesis-testing approach. One alternative would be to avoid statements of "there was no effect" in favour of "no effect could be detected". Better still, use the approach advocated by most biometricians, of treating the aim of an experiment as estimation rather than hypothesis-testing: calculate the size of the difference between means, along with its confidence intervals. The same statistical calculations, different philosophy. The confidence interval may overlap with zero, but we avoid the Type II error trap. In reviews, instead of stamp collecting and tallying how many studies find an effect or no effect, we could produce histograms of the means, so that the distribution of the estimated effect size is explicit.

\subsection{The need to measure traits in a meaningful environment}

We previously touched on why traits measured in low density weed genotype monoculture may differ from those measured in the presence of a crop that modifies the environment substantially. The timing of resource availability, not just its magnitude, will be exaggerated and thus we might expect a small difference between genotypes in early growth to become magnified as a crop grows. Therefore, if our aim is to estimate the size of the fitness cost, not just its occurrence, we reiterate our recommendation that experiments are conducted under realistic field conditions - which includes the presence of appropriate crops or pasture species. Plant scientists are familiar with genotype-by-environment interactions. So, is it reasonable to expect that the relative fitness of two genotypes grown in potting compost with a plentiful supply of water and nutrients, in a glasshouse, without crop competition or other biotic interactions, will be transferable to field conditions where all resources may be severely limited?

Looking at the broader picture, variation in the environment has often been shown to modulate the trait difference between resistance and susceptible genotypes. The type of environmental variation tested has included both abiotic and biotic factors, expectedly leading to variable conclusions. Variations in temperature ${ }^{25,36,61} \square$ and light intensity ${ }^{35,62} \square$ 
have been tested, which is particularly relevant in the case of triazine resistance, known to be primarily endowed by chloroplastic genes. A solid body of work has also tested the interplay of resistance with other defense mechanisms against pathogens and herbivores ${ }^{35,63,64} \square$. This layer of complexity leaves us with two options: to either restrict research to the one field environment in which we are interested, in which case the conclusions may only be valid in that particular environment, or test many environments with the aim of estimating the mean and range of costs across environments. The second option requires considerable work due to the multifactorial design but this would be the best way to assert definite general conclusions about fitness cost.

A practical but yet rigorous approach would be to measure fitness-related traits in multiple environments that reflect the most relevant climatic, edaphic or biotic gradients. There have been at least two studies examining resistance levels and genetic variation of weeds from multiple environments, in order to gather landscape-level information ${ }^{65,66} \square$. The next step would be to measure the most relevant trait as well, so that descriptive models could become functional and any significant GxE interaction for relative fitness could be taken into account. An experimental design specifically capturing an environmental gradient would then allow the interpolation of results within the range of variation observed (but beware of careless extrapolation).

\subsection{Ensuring that the trait is measured between plants that only differ for resistance}

The fitness cost of herbicide resistance emerges as a side effect of the primary response to selection, from different and potentially interconnected mechanisms. It is thus expected that this cost may involve a rather numerous set of epistatic interactions between the resistance alleles and the genetic background considered. Agricultural weeds often have abundant genetic variation segregating within a population ${ }^{67-70} \square$. The distribution of alleles within and across populations is expected to vary more often than not when exposed to selection ${ }^{71} \square$ and this heterogeneity can cause variation in the magnitude of the resulting interactions. As allele frequencies evolve in every generation due to selection and other evolutionary forces, the cost itself is thus also expected to evolve over time ${ }^{72} \square$. There are currently limited means to anticipate these epistatic interactions, most genomic prediction 
methods relying on purely additive models. Using fully isogenic backgrounds through a mutant to wild-type comparison would be valid ${ }^{22} \square$, but considerably limited in scope. Similar to testing a single environment, the conclusion will only be valid for this specific background, which might well be relevant to the case of introgression of resistance alleles in crops but certainly not to all wild weed populations. However, it seems rather presumptuous to assume an even genomic background response when comparing resistant and susceptible accessions on the ground of a similar habitat $\operatorname{origin}^{62} \square$.

Testing all the genetic backgrounds seems even more ambitious than testing all agronomically relevant environmental conditions, and there are no valid methods to transpose results across genetic backgrounds. However, a rigorous starting point would be to homogenise the genetic background through biparental crosses between resistant and susceptible biotypes ${ }^{25,30,35,73} \square$, eventually adding more subtle intercrosses. This approach would also have the advantage of better deciphering the genetic architecture of resistance (recessive, additive or dominant) and disentangling truly pleiotropic effects from linked variation. It has typically been shown that some combination of chloro-nuclear interactions could induce fitness differences in the case of triazine resistance ${ }^{30} \square$. Another more modern option would be to test multiple natural populations, which is more relevant in an applied context ${ }^{33,34} \square$. There has been a decreased interest in analysing the population genetics of weeds in recent years, which is unfortunate given how sequencing technology has boosted our capacities. Investigating the population structure present in a species and differentiation among populations at a larger scale could provide valuable and rigorous evidence of the degree of genetic homogeneity. This would determine unambiguously whether or not it is valid to assume that the distribution of genetic backgrounds is uniform and indicate whether or not most epistatic interactions are acting within a population. If that is the case, a single broad sample may well represent the extent of diversity of the species.

\section{CONCLUSIONS}

Resistance research has no doubt been influenced by the reductionist view built into early conceptual models which coined the simple term "fitness cost"; for whatever reason, this 
soon - misleadingly - became synonymous with the reduction in growth observed in resistant biotypes. The adoption of the term "fitness" has been unfortunate, since we seldom measure fitness strictly according to its formal evolutionary and ecological definition. True, resistance to herbicides can induce a fitness cost and the term fitness has been used and debated widely by evolutionary theoreticians from Darwin to the current day. But there are many inherent practical challenges associated with measuring fitness cost for herbicide resistance; these have been discussed over several decades with increasing thoroughness ${ }^{1,74}$, though strangely with little alteration of research practices. Issues highlighted in reviews include ways to control or to cope with variable genetic backgrounds, the influence of growth conditions, presence or absence of other genotypes, experimental designs and estimation methods, the appropriate stages of the lifecycle to measure and how to combine measurements over different stages. Despite the high quality of some empirical studies (Table 1), the observation that the methodology behind almost every published fitness cost estimate is not the same is more than the concern of academic purists. The inescapable conclusion, that it is unsafe to directly use - or even to merely compare - estimates from different studies or research groups, should surely be of concern to the entire resistance research community?

While there is always an inherent appeal in reducing "the resistance fitness penalty" to a single number, there is a point at which this becomes detrimental. As emphasised in some very hands-on reviews ${ }^{24,74}$, this simplistic representation of fitness cost might reflect very different realities depending on the experiment, potentially leading to truly variable outcomes and conclusions. One number for cost will obscure such valuable information. Fitness is not one single, fixed entity: by its very definition, we expect fitness to be very context-specific and highly sensitive to perturbation. We need studies across genotypes, populations and environments, to establish the extent to which relative traits of resistant genotypes can be expected to vary. This will provide a basis on which to draw conclusions from restricted studies.

How, then, do we settle this frustratingly ineffective debate about appropriate methodology? Not, in our opinion, by trying to reach agreement on one, standard, irrefutable way to measure fitness cost: that would be both an anathema to scientists and 
an impossibility. Indeed, why do we insist on referring to whatever single metric we end up generating as "fitness" when first it is clearly not fitness as usually defined and second we do little with it once we have it? How often are we actually interested in determining fitness per se?

The most common reason given for seeking to measure fitness cost is to build decision tools for resistance management. In other words, to predict population trends of resistant and susceptible phenotypes (i.e. evolution) under a range of scenarios. One way to do this is to estimate the appropriate genotype-specific parameters of a suitable model of the weed lifecycle; the model can then be used to determine what we need to measure. While some of these parameters may also be recognised as "components of fitness" we do not measure them because we need to know about fitness per se. We thus urge the discontinuation of the "fitness cost" labelling of every experiment, instead taking the data for what they truly are and can be used for: measuring differences in processes and traits between resistance and susceptible plants. If there are occasions when fitness - or relative fitness - is truly the metric of interest, then we must define it and demonstrate that it is measured appropriately as the number of individuals a genotype contributes to the next generation. Given the common use of poor methodologies - that continues in the face of reasonable, repeated criticism - it is our personal view that journals, and the societies that publish them, should finally take the lead in apprising their reviewers, editors and authors of these issues and insisting on appropriate standards.

\section{ACKNOWLEDGEMENTS}

Our thanks to Jonny Gressel for the opportunity to write this opinion piece. Thanks also to Paul Neve for provision of advice and information. 


\section{REFERENCES}

1 Gressel J and Segel LA, The paucity of plants evolving genetic resistance to herbicides: Possible reasons and implications. J Theor Biol 75:349-371 (1978).

2 Jasieniuk M, Brûlé-Babel AL, Morrison IN, Brule-Babel AL and Morrison IN, The evolution and genetics of herbicide resistance in weeds. Weed Sci 44:176-193 (1996).

3 Jordan N, Kelrick M, Brooks J and Kinerk W, Biorational management tactics to select against triazine-resistant Amaranthus hybridus: A field trial. J Appl Ecol 36:123-132 (1999).

$4 \quad$ Neve P, Vila-Aiub M and Roux F, Evolutionary-thinking in agricultural weed management. New Phytol 184:783-793 (2009).

5 Colbach N, Chauvel B, Darmency H, Délye C and Le Corre V, Choosing the best cropping systems to target pleiotropic effects when managing single-gene herbicide resistance in grass weeds. A blackgrass simulation study. Pest Manag Sci 72:19101925 (2016).

6 Neve P, Simulation modelling to understand the evolution and management of glyphosate resistance in weeds. Pest Manag Sci 64:392-401 (2008).

7 Haldane JBS, A mathematical theory of natural and artificial selection-I. Trans Cambridge Philos Soc 23:19-41 (1924).

8 Haldane JBS, More precise expression for the cost of natural selection. J Genet 57:351-360 (1960).

9 Hamilton WD, The genetical evolution of social behaviour. I. J Theor Biol 7:1-16 (1964).

10 Orr HA, Fitness and its role in evolutionary genetics. Nat Rev Genet 10:531-539 (2009).

11 Vogwill T, Lagator M, Colegrave $\mathrm{N}$ and Neve $\mathrm{P}$, The experimental evolution of herbicide resistance in Chlamydomonas reinhardtii results in a positive correlation between fitness in the presence and absence of herbicides. J Evol Biol 25:19551964 (2012).

12 Wu C, Davis AS and Tranel PJ, Limited fitness costs of herbicide-resistance traits in Amaranthus tuberculatus facilitate resistance evolution. Pest Manag Sci in press, (2017). 
13 Ashworth MB, Walsh MJ, Flower KC, Vila-Aiub MM and Powles SB, Directional selection for flowering time leads to adaptive evolution in Raphanus raphanistrum (wild radish). Evol App/ 9:619-629 (2016).

14 Renton M, Busi R, Neve P, Thornby D and Vila-Aiub M, Herbicide resistance modelling: past, present and future. Pest Manag Sci 70:1394-1404 (2014).

15 Jasieniuk $M$ and Maxwell BD, Populations genetics and the evolution of herbicide resistance in weeds. Phytoprotection 75:25-35 (1994).

16 Maxwell BD, Roush ML and Radosevich SR, Predicting the evolution and dynamics of herbicide resistance in weed populations. Weed Technol 4:2-13 (1990).

17 Jacquemin $B$, Gasquez $\mathrm{J}$ and Reboud $\mathrm{X}$, Modelling binary mixtures of herbicides in populations resistant to one of the components: evaluation for resistance management. Pest Manag Sci 65:113-121 (2009).

18 Roux F, Paris M and Reboud X, Delaying weed adaptation to herbicide by environmental heterogeneity: A simulation approach. Pest Manag Sci 64:16-29 (2008).

19 Neve P, Diggle AJ, Smith FP and Powles SB, Simulating evolution of glyphosate resistance in Lolium rigidum I: population biology of a rare resistance trait. $\underline{\text { Weed }}$ Res 43:404-417 (2003).

20 Mortimer AM, Ulf-Hansen PF and Putwain PD, Modelling herbicide resistance - A study of ecological fitness, in Resistance '91: Achievements and Developments in Combating Pesticide Resistance, ed. by Denholm I, Devonshire AL and Hollomon DW. Springer, Dordrecht, The Netherlands, pp. 148-164 (1992).

21 Liu C, Bridges ME, Kaundun SS, Glasgow L, Owen MD and Neve P, A generalised individual-based algorithm for modelling the evolution of quantitative herbicide resistance in arable weed populations. Pest Manag Sci 73:462-474 (2017).

22 Délye C, Menchari Y, Michel S, Cadet É and Le Corre V, A new insight into arable weed adaptive evolution: Mutations endowing herbicide resistance also affect germination dynamics and seedling emergence. Ann Bot 111:681-691 (2013).

23 Roux F, Gasquez J and Reboud X, The dominance of the herbicide resistance cost in several Arabidopsis thaliana mutant lines. Genetics 166:449-460 (2004).

24 Vila-Aiub MM, Neve $P$ and Powles SB, Fitness costs associated with evolved herbicide resistance alleles in plants. New Phytol 184:751-767 (2009). 
25 Jacobs BF, Duesing JH, Antonovics J and Patterson DT, Growth performance of triazine-resistant and -susceptible biotypes of Solanum nigrum over a range of temperatures. Can J Bot 66:847-850 (1988).

26 Holt JS, Reduced growth, competitiveness and photosynthetic efficiency of triazineresistant Senecio vulgaris from California. J Appl Ecol 25:307-318 (1988).

27 Kumar $\mathrm{V}$ and Jha $\mathrm{P}$, Growth and reproduction of glyphosate-resistant and susceptible populations of Kochia scoparia. PLoS One 10:e0142675 (2015).

28 Lamego FP, Vidal RA and Burgos NR, Competitiveness of ALS inhibitors resistant and susceptible biotypes of Greater Beggarticks (Bidens subalternans). Planta Daninha 29:457-464 (2011).

29 Park KW, Mallory-Smith CA, Ball DA and Mueller-Warrant GW, Ecological fitness of acetolactate synthase inhibitor-resistant and -susceptible Downy Brome (Bromus tectorum) biotypes. Weed Sci 52:768-773 (2004).

30 Stowe AE and Holt JS, Comparison of triazine-resistant and -susceptible biotypes of Senecio vulgaris and their F1 hybrids. Plant Physiol 87:183-189 (1988).

31 Pedersen BP, Neve P, Andreasen C and Powles SB, Ecological fitness of a glyphosate-resistant Lolium rigidum population: Growth and seed production along a competition gradient. Basic Appl Ecol 8:258-268 (2007).

32 Younginger BS, Sirová D, Cruzan MB and Ballhorn DJ, Is biomass a reliable estimate of plant fitness? Appl Plant Sci 5:1600094(2017).

33 Bravo W, Leon RG, Ferrell JA, Mulvaney MJ and Wood CW, Differentiation of lifehistory traits among Palmer Amaranth populations (Amaranthus palmeri) and its relation to cropping systems and glyphosate sensitivity. Weed Sci 65:339-349 (2017).

34 Van Etten ML, Kuester A, Chang S-M and Baucom RS, Fitness costs of herbicide resistance across natural populations of the common morning glory, Ipomoea purpurea. Evolution (NY) 70:2199-2210 (2016).

35 Gassmann AJ, Resistance to herbicide and susceptibility to herbivores: environmental variation in the magnitude of an ecological trade-off. Oecologia 145:575-585 (2005).

36 Tang $\mathrm{W}, \mathrm{Xu} \mathrm{X}$, Shen $\mathrm{G}$ and Chen J, Effect of environmental factors on germination and emergence of aryloxyphenoxy propanoate herbicide-resistant and -susceptible Asia Minor Bluegrass (Polypogon fugax). Weed Sci 63::669-675 (2015). 
37 Cousens R and Mortimer M, Dynamics of Weed Populations, Cambridge Univ Press, Cambridge (1995).

38 Burton TL and Husband BC, Fitness differences among diploids, tetraploids, and their triploid progeny in Chamerion angustifolium: mechanisms of inviability and implications for polyploid evolution. Evolution 54:1182-1191 (2000).

39 Cousens R, Brain P, O'Donovan JT and O'Sullivan PA, The use of biologically realistic equations to describe the effects of weed density and relative time of emergence on crop yield. Weed Sci 35:720-725 (1987).

40 Cousens RD, Weaver SE, Martin TD, Blair AM and Wilson J, Dynamics of competition between wild oats (Avena fatua L.) and winter cereals. Weed Res 31:203-210 (1991).

41 Cousens RD, Rebetzke GJ and Barnett AG, Dynamics of competition between wheat and oat: II. Effects of dwarfing gene. Agron J 95:1305-1313 (2003).

42 Fournier-Level A, Perry EO, Wang JA, Braun PT, Migneault A, Cooper MD, et al., Predicting the evolutionary dynamics of seasonal adaptation to novel climates in Arabidopsis thaliana. Proc Natl Acad Sci U S A 113: E2812-E2821 (2016).

43 Schwartz LM, Gibson DJ and Young BG, Using integral projection models to compare population dynamics of four closely related species. Popul Ecol 58:285292 (2016).

44 Torra J, Gonzalez-Andujar JL and Recasens J, Modelling the population dynamics of Papaver rhoeas under various weed management systems in a Mediterranean climate. Weed Res 48:136-146, (2008).

45 Renton $\mathrm{M}$ and Chauhan BS, Modelling crop-weed competition: Why, what, how and what lies ahead? Crop Prot 95:101-108 (2017).

46 Gage KL, Gibson DJ, Young BG, Young JM, Matthews JL, Weller SC, et al., Occurrence of an herbicide-resistant plant trait in agricultural field margins. Ecol Evol 5:4161-4173 (2015).

46 Kirkpatrick M, Patterns of quantitative genetic variation in multiple dimensions. Genetica 136:271-284 (2009).

47 Stinchcombe JR, Agrawal AF, Hohenlohe PA, Arnold SJ and Blows MW, Estimating nonlinear selection gradients using quadratic regression coefficients: Double or nothing? Evolution (NY) 62:2435-2440 (2008).

48 Lande R, Arnold SJ and Nov N, The measurement of selection on correlated characters. Evolution 37:1210-1226 (1983). 
49 Debban CL, Okum S, Pieper KE, Wilson A and Baucom RS, An examination of fitness costs of glyphosate resistance in the common morning glory, Ipomoea purpurea. Ecol Evol 5:5284-5294 (2015).

50 Baucom RS and Mauricio R, Fitness costs and benefits of novel herbicide tolerance in a noxious weed. Proc Natl Acad Sci U S A 101:13386-13390, (2004).

51 Délye C, Jasieniuk M and Le Corre V, Deciphering the evolution of herbicide resistance in weeds. Trends Genet 29:649-658, (2013).

52 Osipitan OA and Dille JA, Fitness outcomes related to glyphosate resistance in Kochia (Kochia scoparia): What life history stage to examine? Front Plant Sci 8:1090 (2017).

53 Cousens R, Design and interpretation of interference studies: Are some methods totally unacceptable? New Zeal J For Sci 26:5-18 (1996).

54 Lehnhoff EA, Keith BK, Dyer WE and Menalled FD, Impact of biotic and abiotic stresses on the competitive ability of multiple herbicide resistant wild oat (Avena fatua). PLoS One 8:e64478 (2013).

55 Harper JL, Population Biology of Plants. Acad Press, London (1977).

56 Gressel J and Ben-Sinai G, Low intraspecific competitive fitness in a triazineresistant, nearly nuclear-isogenic line of Brassica napus. Plant Sci 38:29-32, (1985).

57 Cousens R, Aspects of the design and interpretation of competition (interference) experiments. Weed Technol 5:664-673 (1991).

58 Deen W, Cousens R, Warringa J, Bastiaans L, Carberry P, Rebel K, et al., An evaluation of four crop:weed competition models using a common data set. Weed Res 43:116-129 (2003).

59 Cousens R and Marshal C, Dangers in testing statistical hypotheses. Ann Appl Biol 111:469-476, (1987).

60 Roles AJ and Conner JK, Fitness effects of mutation accumulation in a natural outbred population of wild radish (Raphanus raphanistrum): comparison of field and greenhouse environments. Evolution (NY) 62:1066-1075, (2008).

61 Frenkel E, Matzrafi M, Rubin B and Peleg Z, Effects of environmental conditions on the fitness penalty in herbicide resistant Brachypodium hybridum. Front Plant Sci 8:94 (2017). 
62 Shrestha A, Hanson BD, Fidelibus MW and Alcorta M, Growth, phenology, and intraspecific competition between glyphosate-resistant and glyphosate-susceptible horseweeds (Conyza canadensis) in the San Joaquin Valley of California. Weed Sci 58:147-153, (2010).

63 Bergelson J, Purrington CB, Palm CJ and Lopez-Gutierrez JC, Costs of resistance: a test using transgenic Arabidopsis thaliana. Proc R Soc Lond B 263:1659-1663 (1996).

64 Menchari Y, Camilleri C, Michel S, Brunel D, Dessaint F, Le Corre V, et al., Weed response to herbicides: Regional-scale distribution of herbicide resistance alleles in the grass weed Alopecurus myosuroides. New Phytol 171:861-874 (2006).

65 Kuester A, Chang S-M and Baucom RS, The geographic mosaic of herbicide resistance evolution in the common morning glory, Ipomoea purpurea: Evidence for resistance hotspots and low genetic differentiation across the landscape. Evol Appl 8:821-833, (2015).

66 Slotta TAB, Rothhouse JM, Horvath DP and Foley ME, Genetic diversity of Canada thistle (Cirsium arvense) in North Dakota. Weed Sci 54:1080-1085 (2006).

67 Muller $\mathrm{M}-\mathrm{H}$, Latreille $\mathrm{M}$ and Tollon $\mathrm{C}$, The origin and evolution of a recent agricultural weed: population genetic diversity of weedy populations of sunflower (Helianthus annuus L.) in Spain and France. Evol App/ 4:499-514 (2011).

68 Wu H, Qiang S and Peng G, Genetic diversity in Veronica hederifolia (Plantaginaceae), an invasive weed in China, assessed using AFLP markers. Ann Bot Fenn 47:190-198 (2010).

69 Madhou P, Wells A, Pang ECK, Stevenson TW and Porter S, Genetic variation in populations of Western Australian wild radish. Aust J Agric Res 56:1079-1087 (2005).

70 Kuester A, Wilson A, Chang S-M and Baucom RS, A resurrection experiment finds evidence of both reduced genetic diversity and potential adaptive evolution in the agricultural weed Ipomoea purpurea. Mol Ecol 25:4508-4520 (2016).

71 Darmency H, Menchari Y, Le Corre V and Délye C, Fitness cost due to herbicide resistance may trigger genetic background evolution. Evolution (NY) 69:271-278 (2015).

72 Giacomini D, Westra $P$ and Ward SM, Impact of genetic background in fitness cost studies: An example from glyphosate-resistant Palmer Amaranth. Weed Sci 62:2937 (2014). 
73 Vila-Aiub MM, Gundel PE and Preston C, Experimental methods for estimation of plant fitness costs associated with herbicide-resistance genes. Weed Sci 63:203216 (2015).

This article is protected by copyright. All rights reserved. 
Table 1: Example studies containing aspects of particular significance for the measurement of fitness costs associated with herbicide resistance. HR: herbicide resistance, R: resistant, S: susceptible

\begin{tabular}{|c|c|c|c|c|c|c|}
\hline Reference & $\begin{array}{l}\text { Species and } \\
\text { herbicide } \\
\text { resistance }\end{array}$ & Traits measured & $\begin{array}{l}\text { Response to } \\
\text { selection }\end{array}$ & Environment & $\begin{array}{l}\text { Genetic } \\
\text { background }\end{array}$ & Significance \\
\hline $\begin{array}{l}\text { Baucom \& } \\
\text { Mauricio }(2004)^{51}\end{array}$ & $\begin{array}{l}\text { Ipomoea purpurea } \\
\text { resistant to } \\
\text { glyphosate }\end{array}$ & $\begin{array}{l}\text { Exemplary data } \\
\text { collection with measures } \\
\text { of survival, } 10 \text { rounds of } \\
\text { collection of seeds plus } \\
\text { viability assessment }\end{array}$ & $\begin{array}{l}\text { Partial } \\
\text { regression } \\
\text { analysis using } \\
\text { mixed models }\end{array}$ & $\begin{array}{l}\text { Agricultural field } \\
\text { of origin of the } \\
\text { plants, } \\
\text { competitive } \\
\text { weeds left } \\
\text { undisturbed }\end{array}$ & $\begin{array}{l}32 \text { plants from a } \\
\text { natural } \\
\text { population }\end{array}$ & $\begin{array}{l}\text { Seminal study that } \\
\text { was done in field } \\
\text { conditions using } \\
\text { multiple populations } \\
\text { and advanced } \\
\text { statistical modelling. }\end{array}$ \\
\hline $\begin{array}{l}\text { Gassmann } \\
(2005)^{35}\end{array}$ & $\begin{array}{l}\text { Amaranthus } \\
\text { hybridus resistant to } \\
\text { triazine }\end{array}$ & $\begin{array}{l}\text { Herbivores growth and } \\
\text { survival, plant phenolics } \\
\text { and nitrogen }\end{array}$ & NA & $\begin{array}{l}\text { Greenhouse } \\
\text { condition with } 2 \\
\text { levels of light and } \\
2 \text { levels of } \\
\text { nitrogen }\end{array}$ & $\begin{array}{l}\text { F3 lines from } \\
\text { reciprocal } \\
\text { crosses from } 2 \\
\text { natural } \\
\text { populations }\end{array}$ & $\begin{array}{l}\text { One of the rare } \\
\text { studies testing the } \\
\text { effect of multiple } \\
\text { environments. }\end{array}$ \\
\hline $\begin{array}{l}\text { Gage et al. } \\
(2015)^{46}\end{array}$ & $\begin{array}{l}\text { Conyza canadensis } \\
\text { resistant to } \\
\text { glyphosate }\end{array}$ & $\begin{array}{l}\text { Survivorship, height, } \\
\text { rosette diameter, number } \\
\text { of leaves, life stage, and } \\
\text { herbivory at } 11 \\
\text { instances, biomass and } \\
\text { seed weight plus } \\
\text { management history }\end{array}$ & $\begin{array}{l}\text { PCA and } \\
\text { discriminant } \\
\text { analysis, } \\
\text { mixed model } \\
\text { analysis of } \\
\text { covariance } \\
\text { with HR }\end{array}$ & $\begin{array}{l}\text { In-field and } \\
\text { ruderal habitat } \\
\text { tested }\end{array}$ & $\begin{array}{l}\text { Populations from } \\
\text { the margin of } 17 \\
\text { fields surveyed, } 2 \\
\text { populations of } R \\
\text { and } 2 \\
\text { populations of } S \\
\text { tested }\end{array}$ & $\begin{array}{l}\text { Study proposing the } \\
\text { most advanced } \\
\text { statistical tools for } \\
\text { high-dimension } \\
\text { multivariate analysis. }\end{array}$ \\
\hline
\end{tabular}

This article is protected by copyright. All rights reserved. 1 


\begin{tabular}{|c|c|c|c|c|c|c|}
\hline $\begin{array}{l}\text { Van Etten et al. } \\
(2016)^{34}\end{array}$ & $\begin{array}{l}\text { Ipomoea purpurea } \\
\text { resistant to } \\
\text { glyphosate }\end{array}$ & $\begin{array}{l}\text { Germination, early root } \\
\text { and above ground } \\
\text { growth }\end{array}$ & NA & $\begin{array}{l}\text { A single } \\
\text { greenhouse }\end{array}$ & $\begin{array}{l}43 \text { natural } \\
\text { populations plus } \\
\text { a selfing } \\
\text { generation }\end{array}$ & $\begin{array}{l}\text { The greatest number } \\
\text { of natural weed } \\
\text { populations } \\
\text { comprehensively } \\
\text { analysed in a study. }\end{array}$ \\
\hline Wu et al. $(2017)^{69}$ & $\begin{array}{l}\text { Amaranthus palmeri } \\
\text { resistant to } \\
\text { glyphosate, lactofen } \\
\text { and mesotrione }\end{array}$ & $\begin{array}{l}\text { Evolution of } 7 \text { molecular } \\
\text { resistance traits }\end{array}$ & $\begin{array}{l}\text { Evolution of } \\
\text { HR frequency } \\
\text { tested over } 6 \\
\text { generations }\end{array}$ & $\begin{array}{l}\text { Greenhouse } \\
\text { conditions; } \\
\text { planted in plots }\end{array}$ & $\begin{array}{l}\text { multiple } \\
\text { introgression of } \\
\text { herbicide } \\
\text { reistance into a } \\
\text { population of } \\
\text { susceptible } \\
\text { plants }\end{array}$ & $\begin{array}{l}\text { One of the rare } \\
\text { instances of } \\
\text { experimental } \\
\text { evolution in } \\
\text { resistance studies }\end{array}$ \\
\hline $\begin{array}{l}\text { Bravo et al. } \\
(2017)^{33}\end{array}$ & $\begin{array}{l}\text { Amaranthus palmeri } \\
\text { resistant to } \\
\text { glyphosate }\end{array}$ & $\begin{array}{l}23 \text { growth and } \\
\text { morphology traits plus } \\
\text { their ratios, flowering } \\
\text { time and chlorophyll } \\
\text { fluorescence }\end{array}$ & NA & $\begin{array}{l}\text { Outdoor pots } \\
\text { under irrigation }\end{array}$ & $\begin{array}{l}10 \text { natural } \\
\text { populations and } \\
\text { progeny }\end{array}$ & $\begin{array}{l}\text { The most complete } \\
\text { set of traits measured } \\
\text { in a herbicide } \\
\text { resistance study }\end{array}$ \\
\hline
\end{tabular}




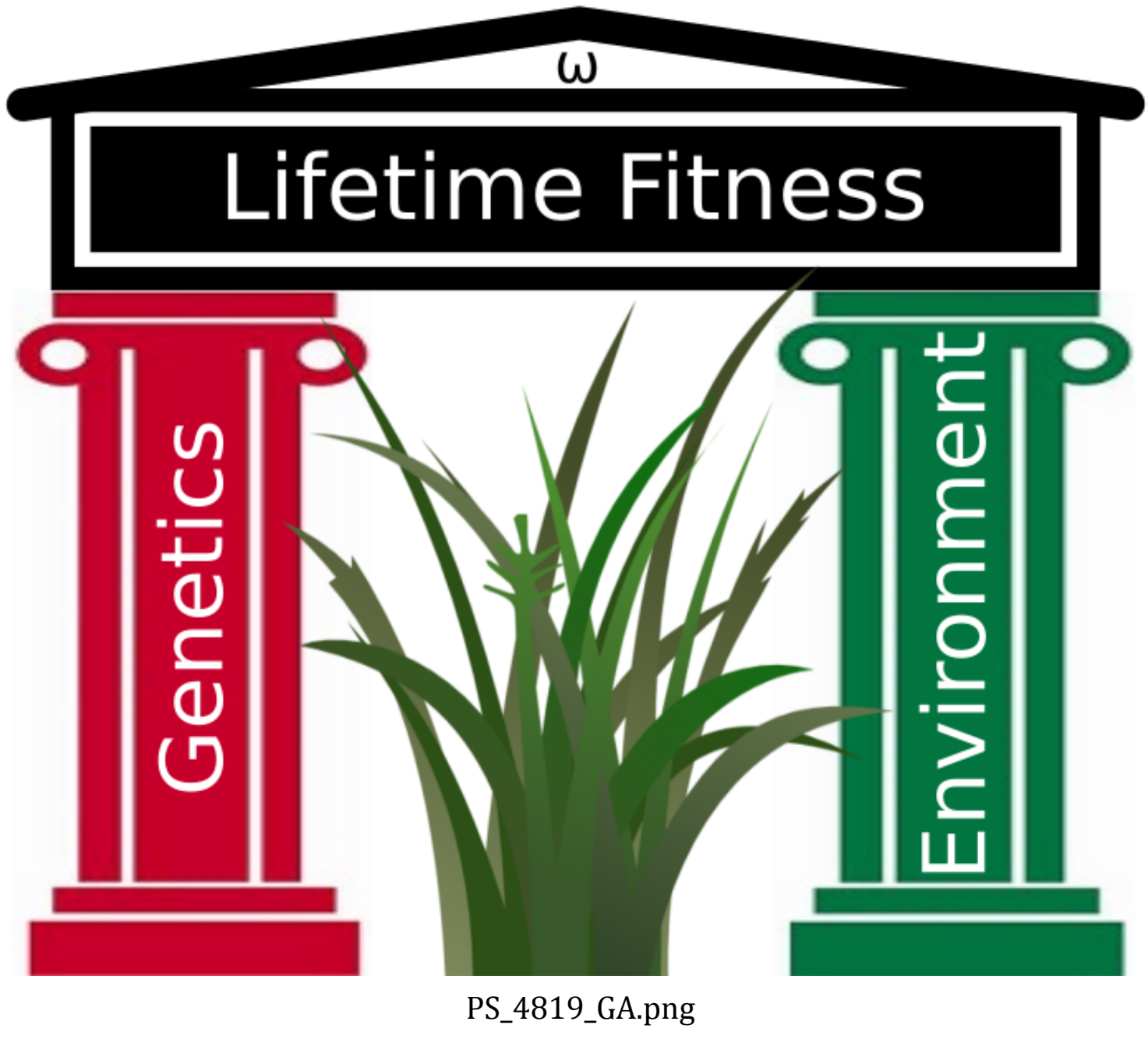

This article is protected by copyright. All rights reserved. 
Herbicide resistance costs: what are we actually measuring and why?

Roger D Cousens and Alexandre Fournier-Level

Herbicide resistance studies often report estimates of any consequent penalty imposed on resistant plants. Experimental designs need to better anticipate sources of variation and purpose of collecting the data.

This article is protected by copyright. All rights reserved. 


\section{University Library}

\section{- M M N E R VA A gateway to Melbourne's research publications}

Minerva Access is the Institutional Repository of The University of Melbourne

Author/s:

Cousens, RD;Fournier-Level, A

Title:

Herbicide resistance costs: what are we actually measuring and why?

Date:

2018-07-01

Citation:

Cousens, R. D. \& Fournier-Level, A. (2018). Herbicide resistance costs: what are we actually measuring and why?. PEST MANAGEMENT SCIENCE, 74 (7), pp.1539-1546. https:// doi.org/10.1002/ps.4819.

Persistent Link:

http://hdl.handle.net/11343/283448 